This chapter summarizes theoretical perspectives and research findings on developmental education, and emphasizes the importance of considering students' voices and experiences in determining how best to facilitate growth and development in college.

\title{
Using Theory and Research to Improve Access and Retention in Developmental Education
}

\author{
Jeanne L. Higbee, David R. Arendale, Dana Britt Lundell
}

Developmental education is an essential part of the community college mission; McCabe and Day (1998) estimate that more than two million students each year would drop out of postsecondary education without participation in one or more developmental education activities. To provide effective developmental education, community colleges should implement best practices that have been proven effective through rigorous research and evaluation based on strong theoretical foundations. This chapter discusses the primary theoretical perspectives that have shaped the profession and provide the foundation for today's professional practice, presents current research that reflects both student and institutional perspectives in evaluating a wide array of developmental education models, and concludes with recommendations for future research.

\section{Theoretical Foundations of Developmental Education}

Although most developmental educators are knowledgeable about the theories that guide their academic disciplines, many admit to lacking training in educational and related theories and do not perceive that there are many professional development opportunities to learn more about theory (Chung and Higbee, 2004). Thus, there is a critical need to link theory, research, and practice in developmental education.

Developmental education, previously known as preparatory, compensatory, or remedial education (Clowes, 1982), was renamed and redefined 
in order to encompass both the academic and noncognitive factors that influence student success in higher education. As Boylan and Saxon (1998) assert, developmental education not only focuses on enhancing students' academic performance but also takes into account "a variety of noncognitive or 'developmental' factors ... [such] as locus of control, attitudes toward learning, self-concept, autonomy, ability to seek help, and a host of other influences having nothing to do with students' intellect or academic skill" (p. 7).

The roots of developmental education as practiced today can be traced to The Student Personnel Point of View, which proposed, "It is the task of colleges and universities to ... assist the student in developing to the limits of his potentialities and in making his contribution to the betterment of society" (American Council on Education, 1937, as reprinted by National Association of Student Personnel Administrators, 1989, p. 39). The Student Personnel Point of View suggested that institutions of higher education promote the growth of "the student as a whole" (p. 39), rather than focusing merely on students' intellectual development. The Student Personnel Point of View was revised in 1949 (American Council on Education, 1949) to include a section on the need for academic assistance programs, and stated that it is the responsibility of colleges and universities to provide counseling and other services to assist students in developing the skills and attitudes necessary for success. Two theoretical frameworks-student development theory and transformative theory-echo the principles embodied in The Student Personnel Point of View and have strongly influenced developmental educators.

Student Development Theory. Arthur Chickering, William Perry, and Alexander Astin are three theorists whose work has guided developmental education since the 1960s. Chickering's (1969) model built on The Student Personnel Point of View's emphasis on the whole student and identified seven vectors of college student development: achieving competence, managing emotions, developing autonomy, establishing identity, freeing interpersonal relationships, clarifying purpose, and developing integrity. Although there were relatively few nontraditional-age students enrolled in America's community colleges at the time Chickering developed his theory, many of the seven vectors also apply to older students who are developing new competencies and reexamining their sense of identity and purpose (Chickering and Reisser, 1993). Chickering's seven vectors can be particularly useful in identifying the competing demands on community college students' time and in demonstrating that development can occur simultaneously in many aspects of students' lives.

Perry's (1970) scheme of ethical and intellectual development is another student development theory that assists developmental educators in understanding student behavior. Perry argued that when students enter college, they are likely to view the world from a dualistic perspective and to look to faculty as authority figures who are there to provide the "right" 
answers. Following Perry's theory that educators must work to move students beyond this dualistic perspective, it is critical that community college developmental educators facilitate students' ability to think for themselves, evaluate the relative merits of different points of view, and make commitments accordingly.

Astin's $(1984,1985)$ theoretical work has also been a primary source of knowledge about college student development. He proposed that instead of viewing higher education as a place to produce "knowledge and trained manpower," educators must embrace a "talent development model," recognizing that where students begin along the educational continuum is not as important as how much they learn and develop (1985, pp. 14, 16). As he noted, "Under this model, the major purpose of any institution of higher education is to develop the talents of its faculty and students to their maximum potential. .. . The verb develop seems more appropriate than the verb produce" (1985, p. 16). Astin's work has encouraged educators to focus on a model that enhances access and retention and stresses the role of developmental education in nurturing students' individual talents. Although much of the research that served as the foundation for Chickering, Perry, and Astin's work was conducted at four-year institutions, these principles apply equally well to community colleges. As noted by Grubb and Worthen in their study of community colleges (1999), "Bridging the gap between the competencies students bring with them and those they need to do well in the classroom and in society is crucial to making them useful members of society" (p. 173).

Transformative Theories. Drawn from democratic theory, multicultural education theory, and other transformative perspectives, "Transformative education ... places the student's reflective processes at the core of the learning experience and asks the student to evaluate both new information and the frames of reference through which the information acquires meaning" (American College Personnel Association and National Association of Student Personnel Administrators, 2004, p. 9). In the 1990s, postsecondary educators articulated a new emphasis on learning rather than teaching (Barr and Tagg, 1995), and developmental educators embraced this paradigm shift (Arendale, 1997). More recently, the American College Personnel Association and the National Association of Student Personnel Administrators (2004) asserted that "learning, as it has historically been understood, is included in a much larger context that requires consideration of what students know, who they are, what their values and behavior patterns are, and how they see themselves contributing to and participating in the world in which they live" (pp. 9-10). This message is particularly important to developmental educators working in community colleges, where attending classes is often but one of many commitments that students must balance. It is critical that developmental educators attend to the lived experiences of their students and focus on affective and cultural aspects of learning, not just on the cognitive domain. 
Thus, it is not enough for developmental educators to be knowledgeable about the theories that guide their individual disciplines; they must also explore how individual students construct knowledge and interact with the institution, examine their own attitudes, and identify sources of inequities in higher education. By applying student development and transformative theories to their practice, developmental educators can have a long-term impact on access and retention while also establishing frameworks for conducting research about how students learn and develop.

\section{Understanding Developmental Education Through Student Voices}

Research on college students related to issues of access, learning support, retention, and preparation has gained momentum in recent decades. This research encompasses a broad range of issues, such as learning communities, attrition and retention, the impact of programmatic features on student performance, and student outcomes in developmental programs. Scholars have primarily taken a quantitative approach toward studying these areas; few have centrally featured student voices and the nature of their educational experiences.

Research that listens more directly to students' voices and perceptions of their own college experiences includes case studies, interviews, surveys, and focus groups. Developmental education can benefit greatly from this type of research, especially longitudinal studies that track students through their college transitions and explore changes in attitudes, beliefs, achievement, identity, and self-perceptions. In addition, by focusing on issues of access and preparation, researchers can provide information about possible barriers, motivational issues, diversity and cultural factors, and students' learning orientations. Future research that connects the characteristics of students in developmental programs with research on access and retention will help improve teaching and learning in community colleges.

In the past five years a number of articles have been published featuring developmental students' perspectives, and many used qualitative approaches to gathering data about students in developmental education courses and programs (Beach, Lundell, and Jung, 2002; Cole, Goetz, and Wilson, 2000; Valeri-Gold and others, 2001). These qualitative studies are extremely important, and their results have the potential to reshape community college practices. For example, an educator might know quantitatively how a student is performing in a course based on traditional measures such as grade point average, specific exam grades, and other achievement markers. However, when a student arrives underprepared for college or is underperforming in a first-year course, learning more about the nature of this student's experience, including the influence of cultural background or peer and family communities, may produce further insights into improving performance. Because students' experiences are richly layered and complex, 
researching underlying causes and perceptions through listening to student voices can strengthen the work of developmental educators.

It is also important to look at the results of research on student voices outside the field of developmental education. Key qualitative studies have examined college student development, workforce transitions, and multicultural issues, and these studies should be included as reference points for the future work of community colleges (see, for example, Baxter Magolda, 2001; Light, 2001).

\section{Models of Developmental Education}

A wide variety of developmental education models exist, and the effectiveness of each varies among both community colleges and their students. The diversity of these models is a result of different underlying learning theories, policies, funding formulas, student population characteristics, historical traditions, political decisions, and state and local stakeholder expectations (Boylan, 2002). Despite this diversity, developmental education programs can be broadly categorized into two groups: prerequisite acquisition models and concurrent acquisition models.

Prerequisite Acquisition Models. Many underprepared community college students must participate in prerequisite remedial or developmental courses before they can enroll in classes that carry credit toward a degree or certificate. Remedial courses in English and mathematics were designed to ameliorate knowledge and skill deficiencies for students entering college. Beginning in the 1860s, this medical model approach, which focused on a "remedy" or "cure" rather than a more holistic approach to students' intellectual development, identified certain students considered in need of "treatment" because they were "academically backward or less able" (Clowes, 1982 , p. 8). These courses are often criticized because many assume that the focus is on academic content usually covered in middle school or early high school. In addition, remedial classes that are offered without additional coordinated academic support activities have mixed outcomes for students (Roueche and Roueche, 1999).

Developmental courses, in contrast to remedial courses, focus on student strengths and address both cognitive and affective development in order to provide skills that are needed for success both in college and in life. Typical developmental courses include introductory algebra, college textbook reading, strategic learning, and basic composition. The findings from research studies that examine the effectiveness of these courses are also mixed. Grubb and Associates (1999) suggested that high course withdrawal and failure rates may be related to student boredom with classes in which skill and drill activities that bear little relationship to credit-bearing courses predominate.

Concurrent Acquisition Models. These models allow students to enroll in developmental and credit-bearing courses simultaneously. 
Concurrent acquisition models can be further divided into three types: adjunct learning experiences for targeted "high-risk" content courses; coordinated programs that require student participation in developmental activities outside of class; and developmental education models that are embedded, infused, or mainstreamed into a content course in order to provide academic support and enrichment.

Examples of the adjunct approach include learning assistance centers, supplemental instruction, and tutoring. Learning assistance centers, especially those that work closely with course instructors, can be very beneficial for students. However, because enrollment is voluntary, not all students will take advantage of them. Supplemental instruction is a model in which students voluntarily attend out-of-class study review sessions, facilitated by fellow students, which integrate content and study skills. Supplemental instruction is one of the most widely adopted adjunct developmental education models in postsecondary education, and many studies have demonstrated its effectiveness (Arendale, 2004). Tutoring can also be an effective adjunct model, although most studies show that outcomes are better when tutors are trained personnel (Boylan, Bliss, and Bonham, 1997; Maxwell, 1997). However, most of these studies lack comparison groups, so it is difficult to estimate the impact of tutoring. Although learning assistance centers, supplemental instruction, and tutoring can all be effective models for providing developmental education, a big disadvantage of all of these voluntary adjunct experiences is that students who lack help-seeking behaviors-often those most at risk for academic failure-may not choose to participate (Dembo and Seli, 2004).

Unlike adjunct models, coordinated developmental education models require students to participate in activities that occur outside of the targeted content class but are closely coordinated with what occurs inside. An example of a coordinated program is the linked or paired course model. Students concurrently enroll in two courses: a content course (for example, Introduction to Psychology) and a learning strategies course. Cognitive learning strategies are applied to assignments and reading requirements from the content course, thus providing the opportunity for immediate application and reinforcement of both content and basic skills. Several studies have shown this model to be extremely effective in educating developmental students (McCabe and Day, 1998; Tinto, 1997).

Another variation on the coordinated approach is to require all students to participate in additional discussion sessions that integrate both academic content and learning strategy practice. Faculty coordinate the curricula and supervise discussions, which are led by a trained student. This approach improves on adjunct developmental education models by ensuring that all students participate in the enrichment activities, especially those who are least likely to seek the opportunity on their own. Hundreds of colleges across the country have adopted these programs as research has shown them to support positive student outcomes (Arendale, 2004). Two 
extremely successful examples of required discussion session programs are the Emerging Scholars Program at the University of California, Berkeley (Treisman, 1986) and Peer-Led Team Learning at The City College of New York (Dreyfus, 2003).

In embedded, infused, or mainstreamed developmental education models, best practices are directly integrated by the primary course instructor into classroom learning experiences. The course curriculum and the classroom environment are transformed through simultaneous instruction in both academic content and learning strategies. This seamless integration provides enriched learning experiences for all students and eliminates the need for prerequisite or adjunct courses, thereby saving time and money for both students and the institution. Successful embedded or infused developmental education models are federated learning communities (Malnarich and Associates, 2003) and the University of Minnesota General College approach (Higbee, Lundell, and Arendale, forthcoming).

\section{Recommendations for Future Research}

Although numerous studies have shaped the practice of developmental education, there are a number of areas in which further research is necessary before definitive judgments can be made about its effectiveness. New areas of research have emerged in response to changing demographics and political realities, ongoing scholarship across educational levels, and improved research protocols and procedures.

Assess Affective Barriers to Student Achievement. Much of the assessment that occurs in developmental education programs is related to admissions, testing and placement, and student success rates. Further assessment is needed that takes into account the affective barriers to student achievement. In order to facilitate the academic success of all learners, developmental education programs should use multiple measures to explore students' motivation, academic autonomy, and potential sources of stress. Although many formal measures are available, developmental educators can also create their own assessment devices, such as questionnaires and protocols for interviews and focus groups. Educators can also gain valuable information by inviting students for informal, individual appointments early in the academic term.

Evaluate Program Effectiveness. In order for developmental education programs to remain viable, it is imperative that their effectiveness be evaluated. For example, research should be conducted to determine whether students who complete developmental education courses are successful in subsequent, related, credit-bearing courses. In addition, developmental educators might consider the following questions in order to assess their programs and services.

What are the essential elements and components of our institution's developmental education model? In order to create the most cost-effective and 
successful programs, educators need to understand which specific activities and components of developmental education are essential and which can be discarded. King, Morris, and Fitz-Gibbon (1987) argue that limiting evaluation solely to program outcomes only answers the question "Did it work?" and does not address the deeper question "What worked and what did not?" (p. 9). Research that focuses on the process of the intervention in addition to the final product can yield valuable information that can be used in program revision and improvement.

Why is it that all students who need developmental education do not participate in it and that all participants do not achieve positive outcomes? As community college students become more and more diverse, learning theories that are sensitive to individual differences become increasingly relevant, and even essential. Some students do not avail themselves of developmental opportunities for cultural reasons; some simply lack confidence or have not yet developed help-seeking behaviors. Research on elementary and secondary education has focused considerable attention on these two areas and can serve as a basis for further investigation with community college students.

How can developmental education best practices become integrated in firstyear courses? An increasing number of educators believe that developmental education can provide richer and more productive learning experiences for all students and can teach essential lifelong skills needed on the job and for informed citizenship. Careful research is needed to understand how classroom instructors in varied academic disciplines can effectively and efficiently embed best practices into their courses while maintaining academic rigor.

Which developmental education practices are effective, both in cost and in practice? There is currently no central location where educators and scholars can access a wide collection of carefully researched and evaluated developmental education programs. Although the standards published by the Council for the Advancement of Standards and the National Association for Developmental Education (Clark-Thayer, 1995) are a positive start, a central database that contains examples of rigorously evaluated developmental education practices is needed.

Engage in Qualitative Research. Although many of the preceding research questions can be addressed using quantitative methods, qualitative research contributes important knowledge to complex issues of access and retention in developmental education. Interviews, focus groups, and classroom observations provide information about students' perceptions of their educational experiences that cannot be captured or defined through traditional quantitative measures. Qualitative research brings a more nuanced view of the complexity of students' lived experiences and complements the more generalizable data that are gained through quantitative measures.

There are three primary and highly significant benefits of using qualitative methods to assess developmental education. First, they can illuminate the multiple and shifting realities of students in transition. Second, they can 
decrease the stigma of developmental programs by demonstrating the richness and overlapping variety of both developmental and nondevelopmental students' experiences. Stigma results from a lack of knowledge about the real lives of students and the realities of developmental education, and qualitative research can help supply that knowledge. Third, qualitative methods allow educators to explore more meaningfully the complexity of students' multicultural issues in developmental programs. Qualitative research can transform the work of community college administrators, educators, and students, and can be very helpful in improving developmental education programs and services.

Many community college educators are already incorporating qualitative assessment methods into their programs' evaluations, and this work adds to the knowledge base that informs developmental education. This research approach faces some barriers, however, including a lack of acknowledgment or appreciation for the underlying value of this kind of data and the limited time educators have available to conduct longitudinal research. Despite these barriers, becoming familiar with research on college students can help practitioners understand the key issues students face as they persist and succeed in the community college. Finally, this research must be designed from a solid theoretical base to ensure its reliability, validity, and direct connection to ongoing research. Qualitative research that values students' direct experiences, and researchers who listen to students' voices, will continue to provide useful information to community college educators and administrators.

\section{Conclusion}

Knowledge of relevant theory and research is essential if educators are to implement best practices in community college developmental education. Recent efforts such as the Twin Cities Metropolitan Higher Education Consortium's Developmental Education Initiative (Lundell, Higbee, and Hipp, 2004) demonstrate how faculty and staff from community colleges and research universities can collaborate to strengthen learning and support for students across institutions. Students are also an excellent resource for learning about the real impact of developmental practices and programs. It is essential that their viewpoints be recognized and reflected in the future work of the field. Expanding the conversation about developmental models, engaging in more collaborative research on best practices, and sharing results widely can help ensure a brighter future for community college participants in developmental education.

\section{References}

American College Personnel Association and National Association of Student Personnel Administrators. Learning Reconsidered: A Campus-Wide Focus on the Student Experience. Washington, D.C.: American College Personnel Association and National Association of Student Personnel Administrators, 2004. 
American Council on Education. The Student Personnel Point of View. Washington, D.C.: American Council on Education, 1937.

American Council on Education. The Student Personnel Point of View (rev. ed.). Washington, D.C.: American Council on Education, 1949.

Arendale, D. "Leading the Paradigm Shift from Teaching to Learning." National Association for Developmental Education Newsletter, 1997, 20(3), 1.

Arendale, D. (ed.). "Postsecondary Peer Cooperative Learning Programs Annotated Bibliography," 2004. http://www.tc.umn.edu/ arend011/Peerbib03.pdf. Accessed June 24, 2004.

Astin, A. W. "Student Involvement: A Developmental Theory for Higher Education." Journal of College Student Personnel, 1984, 25, 297-308.

Astin, A. W. Achieving Educational Excellence. San Francisco: Jossey-Bass, 1985.

Barr, R., and Tagg, J. "From Teaching to Learning-A New Paradigm for Undergraduate Education." Change Magazine, 1995, 27(6), 12-26.

Baxter Magolda, M. B. Making Their Own Way: Narratives for Transforming Higher Education to Promote Self-Development. Sterling, Va.: Stylus, 2001.

Beach, R., Lundell, D. B., and Jung, H. J. "Developmental College Students' Negotiation of Social Practices Between Peer, Family, Workplace, and University Worlds." In D. B. Lundell and J. L. Higbee (eds.), Exploring Urban Literacy and Developmental Education. Minneapolis: Center for Research on Developmental Education and Urban Literacy, General College, University of Minnesota, 2002. http://www.gen.umn.edu/research/ crdeul. Accessed Aug. 5, 2004.

Boylan, H. R. What Works: Research-Based Best Practices in Developmental Education. Boone, N.C.: Continuous Quality Improvement Network with the National Center for Developmental Education, 2002.

Boylan, H. R., Bliss, L., and Bonham, B. "Program Components and Their Relationship to Student Performance." Journal of Developmental Education, 1997, 20(3), 2-9.

Boylan, H. R., and Saxon, D. P. "The Origin, Scope, and Outcomes of Developmental Education in the 20th Century." In J. L. Higbee and P. L. Dwinell (eds.), Developmental Education: Preparing Successful College Students. Columbia: National Resource Center for the First Year Experience and Students in Transition, University of South Carolina, 1998.

Chickering, A. W. Education and Identity. San Francisco: Jossey-Bass, 1969.

Chickering, A. W., and Reisser, L. Education and Identity (2nd ed.). San Francisco: Jossey-Bass, 1993.

Chung, C. J., and Higbee, J. L. "Addressing the 'Theory Crisis' in Developmental Education: Ideas from Practitioners in the Field." Unpublished manuscript, University of Minnesota, Minneapolis, 2004.

Clark-Thayer, S. (ed.). National Association for Developmental Education Self-Evaluation Guides: Models for Assessing Learning Assistance/Developmental Education Programs. Clearwater, Fla.: H and H Publishing, 1995.

Clowes, D. A. "More Than a Definitional Problem: Remedial, Compensatory, and Developmental Education." Journal of Developmental and Remedial Education, 1982, 4(2), 8-10.

Cole, R. P., Goetz, E. T., and Wilson, V. "Epistemological Beliefs of Underprepared College Students." Journal of College Reading and Learning, 2000, 31(1), 60-72.

Dembo, M. H., and Seli, H. P. "Students' Resistance to Change in Learning Strategies Courses." Journal of Developmental Education, 2004, 27(3), 2-4, 6, 8, 10-11.

Dreyfus, A. E. (ed.). "Peer-Led Team Learning," 2003. http://www.pltl.org. Accessed Nov. 1, 2004.

Grubb, W. N., and Associates. Honored but Invisible: An Inside Look at Community College Teaching. New York: Routledge, 1999.

Grubb, W. N., and Worthen, H. "Remedial/Developmental Education: The Best and the Worst." In W. N. Grubb and Associates (eds.), Honored but Invisible: An Inside Look at Community College Teaching. New York: Routledge, 1999. 
Higbee, J. L., Lundell, D. B., and Arendale, D. R. Integrating Intellectual Growth, Multicultural Perspectives, and Student Development: The General College Model. Minneapolis: Center for Research on Developmental Education and Urban Literacy, General College, University of Minnesota, forthcoming.

King, J. A., Morris, L. L., and Fitz-Gibbon, C. T. How to Assess Program Implementation. Thousand Oaks, Calif.: Sage, 1987.

Light, R. Making the Most of College: Students Speak Their Minds. Cambridge, Mass.: Harvard University Press, 2001.

Lundell, D. B., Higbee, J. L., and Hipp, S. Metropolitan Higher Education Consortium Developmental Education Initiative: Meeting the Needs of Under-Served Students in the Twin Cities Metropolitan Area. Minneapolis: Center for Research on Developmental Education and Urban Literacy, General College, University of Minnesota, 2004. http://www.gen.umn.edu/research/crdeul/consortium.htm. Accessed Nov. 19, 2004.

Malnarich, G., and Associates. The Pedagogy of Possibilities: Developmental Education, College-Level Studies, and Learning Communities. National Learning Communities Project Monograph Series. Olympia: The Evergreen State College, Washington Center for Improving the Quality of Undergraduate Education, in cooperation with the American Association of Community Colleges, 2003.

Maxwell, M. Improving Student Learning Skills. San Francisco: Jossey-Bass, 1997.

McCabe, R., and Day, P. Developmental Education: A Twenty-First Century Social and Economic Imperative. Mission Viejo, Calif.: League for Innovation in the Community College, 1998.

National Association of Student Personnel Administrators. Points of View. Washington, D.C.: National Association of Student Personnel Administrators, 1989.

Perry, W. G. Forms of Intellectual and Ethical Development in the College Years: A Scheme. Austin, Tex.: Holt, Reinhart and Winston, 1970.

Roueche, J. E., and Roueche, S. D. High Stakes, High Performance: Making Remedial Education Work. Washington, D.C.: Community College Press, 1999.

Tinto, V. "Classroom as Communities: Exploring the Educational Character of Student Persistence." Journal of Higher Education, 1997, 68(6), 599-623.

Treisman, P. U. "A Study of the Mathematics Performance of Black Students at the University of California, Berkeley." Dissertation Abstracts International, 1986, 47(5), 1641.

Valeri-Gold, M., and others. "Examining College Developmental Learners' Reasons for Persisting in College: A Longitudinal Retention Study." Research and Teaching in Developmental Education, 2001, 17(2), 27-40.

JEANNE L. HIGBEE is professor and senior adviser for research in the Center for Research on Developmental Education and Urban Literacy, General College, University of Minnesota.

DAVID R. ARENDALE is assistant professor and adviser for outreach in the Center for Research and Developmental Education and Urban Literacy, General College, University of Minnesota.

DANA BRITT LUNDELL is program director for the Center for Research on Developmental Education and Urban Literacy, General College, University of Minnesota. 